\title{
The first record of Dendrothrips aspersus (Thysanoptera: Thripidae) from Iran
}

\author{
K. Minaei \\ Department of Plant Protection, College of Agriculture, Shiraz University, Shiraz, Iran
}

\begin{abstract}
The species Dendrothrips aspersus Bhatti, 1971 is reported for the first time from Iran, based on the materials collected on grasses. This species was endemic to their originated region and is recorded for the first time outside their native range. The host records of $D$. aspersus in both India and Iran are discussed. Moreover, the number of thrips species that have been recently recorded from Iran are tabulated.
\end{abstract}

\section{Introduction}

In the most recent treatment of the insect order Thysanoptera, 9 families have been recognised (Mound, 2011b). However, most of the species belongs to these two families: Phlaeothripidae and Thripidae. Although Thripidae is the second largest family of Thysanoptera, it is much more abundant than Phlaeothripidae in temperate regions (ThripsWiki, 2015), and this situation is also true for Iran, where 125 species (including one species group) of

Correspondence: Kambiz Minaei, Department of Plant Protection, College of Agriculture, Shiraz University, Shiraz, Iran.

E-mail:kminaei@shirazu.ac.ir

Acknowledgements: I am grateful to L. A. Mound (CSIRO, Canberra, Australia) as well as K. Tyagi (Molecular Systematics Division, Zoological Survey of India, Kolkata, India) for help me in identification of the species discussed in this paper. J. S. Bhatti kindly sent me a copy of his valuable paper on Indian Dendrothrips. Two anonymous reviewers provided me with detailed criticisms and corrections to an earlier draft.

Key words: Dendrothripinae; Iran, grass; new record; thrips.

Received for publication: 9 February 2015.

Revision received: 14 June 2015.

Accepted for publication: 14 June 2015.

CC Copyright K. Minaei, 2015

Licensee PAGEPress, Italy

Journal of Entomological and Acarological Research 2015; 47:5090

doi:10.4081/jear.2015.5090

This article is distributed under the terms of the Creative Commons Attribution Noncommercial License (by-nc 3.0) which permits any noncommercial use, distribution, and reproduction in any medium, provided the original author(s) and source are credited.
Thripidae versus 45 species of Phlaeothripidae (Minaei, 2013) were collected. A large proportion of thripids are flower and leaf-feeders.

In Iran, three genera (Dendrothrips Usel, Iranodendrothrips Alavi, Minaei \& Fekrat, Pseudodendrothrips Schmutz) with seven species are known in Dendrothripinae. An identification key for those genera and species including four species in Dendrothrips are also available (Alavi et al., 2014). The purpose of this paper is to report Dendrothrips aspersus as the fifth species in this genus in Iran. This is also the first record of this species outside India.

\section{Materials and methods}

Thrips specimens were collected into ethanol (70\%) and then mounted on to the glass slides in Canada balsam. The photomicrographs and measurements were taken using a Motic BA310 microscope with Motic Image Plus 2.0 ML software. Most of the specimens are deposited in Department of Plant Protection, Shiraz University, Iran (PPSU) with two females in Australian National Insect Collection, Canberra (CSIR0).

\section{Results}

\section{Dendrothrips aspersus Bhatti, 1971}

Dendrothrips aspersus Bhatti, 1971: 349.

FEMALE MACROPTERA: Body generally yellow (Figure 1), antennal segments V-VIII brown; pronotum yellow with brown spots medially and anterolaterally; tergites with brown markings on lateral thirds, two pairs of longitudinal markings joined by two transverse markings on III-VII, but the posterior transverse marking usually absent on II and V; forewing white with three brown spots; major body setae pale.

Antennae 8-segmented (Figure 2A), segments III and IV each with simple sense-cones, III to VI each with two to five rows of microtrichia on dorsal and ventral surface; segments V cylindrical; VI not constricted basally, its inner sense-cone exceeding apex of segment VIII.

Head transverse (Figure 2B), wider than long; ocellar setae pair I absent, pairs II and III minute, ocellar setae III located just outside the triangle (in front of posterior ocelli).

Pronotum wider than long (Figure 2B), granulate, without distinct transverse lines, with no elongate setae, shallowly concave at each side near posterior margin, with about 20 discal setae; posterior margin with about 10 setae; ferna divided; prospinasterum well developed. Mesonotum sculptured with transverse anastomosing striae (Figure 2C), without campaniform sensilla; pair of median setae sit- 
uated medially. Metascutum reticulate distinctively with no campaniform sensilla, pair of minute median setae situated far from anterior margin. Forewing with 3 grayish spots along anterior margin and one next to scale along posterior margin, not covered with microtrichia, with costal margin downturned, scale with three to four veinal seate and one discal seta; remaining wing setae small and finely acute. Tarsi one-segmented.

Lateral sides of abdominal tergites II-VIII with reticulations; tergites III to VII with microtrichia along posterior margin behind S1 and S2 setae; tergite VIII with posteromarginal comb complete; tergites IX and $X$ with some rows of microtrichia; tergite IX longer than tergite $X$, $\mathrm{S} 1$ slightly longer than $\mathrm{S}$; ; tergite $\mathrm{X}$ not divided (Figure 2D).

REMARKS: The species is distinguished from other recorded species of Dendrothrips in Iran (D. phyllireae, D. saltatrix, D. karnyi, $D$. deggeri) by the absence of prominent posteroangular setae as well as eight segmented antennae. The posteroangular setae are not developed in both deggeri and phyllireae as do in aspersus. However, the number of antennal segments in deggeri and phyllireae are 9 and 7 respectively while this is 8 for aspersus.

MEASUREMENTS (one female, in micrometers): Body length 910 . Head, length (width across cheeks) 78 (157). Pronotum median length (width) 92 (183). Fore wing length 6665. Tergite IX median length S1 setae length 40, S2 setae length 43. Ovipositor length 160. Antennal segments I-VIII length: 22, 26, 30, 28, 26, 22, 9, 11.

MATERIAL STUDIED: Iran, Fars province, Shiraz, 1 female on Cynodon dactylon, 15.viii.2014 (KM 1241) (in ANIC); same locality and plant, 2 females, 16. viii.2014 (KM 1243); same locality and plant, 3 females, 29. viii. 2014 (KM 1250); same locality and plant, 6 females (1 in ANIC), 5. ix. 2014 (KM 1255, 1256).

\section{Discussion and conclusions}

Dendrothrips aspersus was described by Bhatti in 1971 from India based on specimens collected on Zizyphus flowers (family Rhamanaceae) and leaves of Acacia (family Fabaceae) with an identification key to 13 species of Dendrothrips. Recently, Bhagat (2011) collected this species on the same plants from Jammu and Kashmir state of India. There is no report of this species outside India, so this

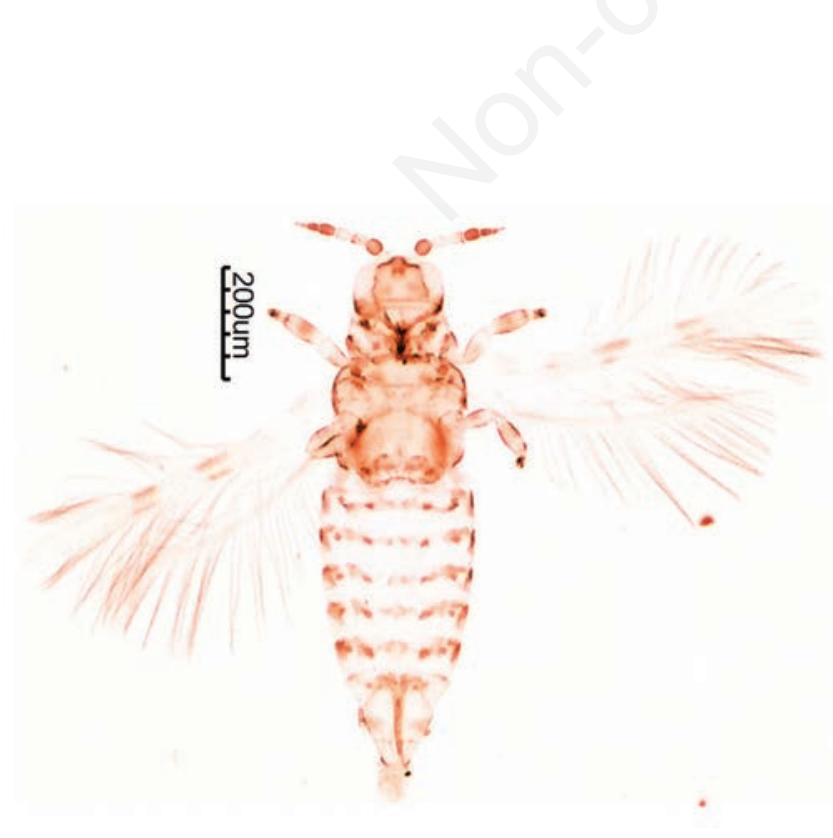

Figure 1. Dendrothrips aspersus, female. is the first record outside this sub-continent. The fauna of Iran shares many species with the European Mediterranean area (Minaei, 2013), but Oriental region has also a considerable influence on the Iranian fauna. The presence of $D$. aspersus in Iran confirms that statement.

The species of the genus Dendrothrips are mainly associated with two plant families, Oleaceae and Flacourtiaceae (Marullo, 2003), however, two species have been collected on Vitex sp (Fam. Lamiaceae). These include D. minutus (Ananthakrishnan, 1961) as well as D. karnyi (zur Strassen, 2003). Furthermore, D. aspersus has just apparently collected on Ziziphus sp. and Acacia sp. Despite the foregoing, all specimens of $D$. aspersus in this study were collected from leaves of grasses (family Poaceae), which were grown up in an olive garden, but there are no documents, which demonstrate that olive (family Oleaceae) may be a host for the species. The host plant recognition in Thysanoptera is difficult (Mound, 2013). Mound (1999, 2011a) demonstrated that among Dendrothripinae, none of Dendrothrips species is associated with grasses.

From the last two decades the number of thrips species described or recorded in Iran increased. Minaei (2013) reported 202 species (including one species group) from Iran. Later on, 19 species including one new genus and 10 new species have been recorded from Iran (Table 1). Some of the species were synonymised (Table 2), considering the reports of Thrips viminalis (Rahemi et al., 2010), of two Haplothrips species, H. cahirensis (Trybom 1911) and H. knechteli Priesner (Fallahzadeh \& Saghaei, 2012) not in Minaei checklist (Minaei, 2013), the number of species of Thysanoptera known from Iran grows to 223 .

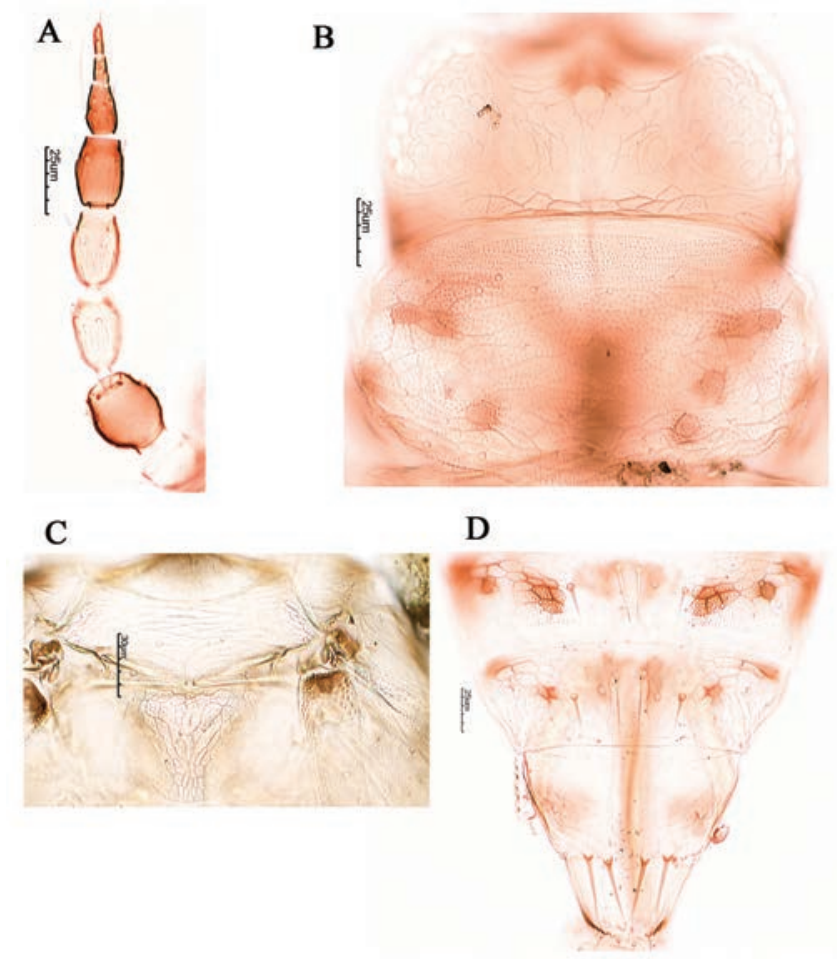

Figure 2. Dendrothrips aspersus, female. A) Antenna; B) Head and pronotum; C) Mesonotum and metanotum; D) Abdominal tergites VII-X. 
Table 1. The species recorded in Iran after the Checklist by Minaei (2013).

\begin{tabular}{|c|c|c|}
\hline Species* & Family & Reference \\
\hline Aeolothrips melaleucus & Aeolothripidae & Minaei, 2014b \\
\hline Anaphothrips microptera & Thripidae & Mirab-balou et al., 2014b \\
\hline Eremiothrips eshghii & Thripidae & Minaei, 2014a \\
\hline Eryngyothrips banihashemii & Thripidae & Minaei et al., 2014 \\
\hline Haplothrips verbasci & Phlaeothripidae & Mirab-balou, 2014a \\
\hline Iranodendrothrips kamalii & Thripidae & Alavi et al., 2014 \\
\hline Karnyothrips flavipes & Phlaeothripidae & Miramirkhani et al., 2014 \\
\hline Neohydatothrips ilamensis & Thripidae & Mirab-balou et al., 2014a \\
\hline Nesothrips brevicollis & Phlaeothripidae & Mirab-balou, 2014b \\
\hline Mycterothrips mahvelatensis & Thripidae & Alavi et al., 2013 \\
\hline Mycterothrips nastarani & Thripidae & Alavi et al., 2013 \\
\hline Mycterothrips sanubari & Thripidae & Alavi et al., 2013 \\
\hline Psilothrips zygophylli & Thripidae & Minaei \& Mound, 2015 \\
\hline Scolothrips dilongicornis & Thripidae & Fekrat \& Manzari, 2014 \\
\hline Scolothrips tenuipennis & Thripidae & Minaei \& Abdollahi, 2015 \\
\hline Sitothrips izadpanahi & Thripidae & Minaei \& Mound, 2014b \\
\hline Thrips juniperinus & Thripidae & Gholami et al., 2014 \\
\hline Thrips italicus & Thripidae & Jahangiri et al., 2014 \\
\hline Thrips longiceps (Bagnall) & Thripidae & Mirab-balou, 2013 \\
\hline
\end{tabular}

Table 2. Nomenclature changes in thrips species recorded in Iran after the Checklist by Minaei (2013).

\begin{tabular}{lcc} 
Species & Change & Reference \\
Haplothrips cerealis & Synonymised with H. tritici & Minaei \& Mound, 2014a \\
Ataliothrips reuteri & Moved to Liothrips & Minaei \& Mound, 2014c \\
\hline
\end{tabular}

\section{References}

ALAVI J., MINAEI K., FEKRAT L., 2014 - The Iranian Dendrothripinae (Thysanoptera: Thripidae) with description of a new genus and species. - Zootaxa 3860: 479-486.

ALAVI J., MODARRES AWAL M., FEKRAT L., MINAEI K., 2013 - The genus Mycterothrips (Thysanoptera: Thripidae) in Iran, with three new species. - Zootaxa 3718: 345-356.

ANANTHAKRISHNAN T.N., 1961 - Studies on some Indian Thysanoptera VI. - Zool. Anzieger 167: 259-271.

BHAGAT R.C., 2011 - Species richness and Host-plant diversity of Thrips (Thripidae: Thysanoptera) in Jammu \& Kashmir. Indian J. Appl. Pure Biol. 26: 85-89.

BHATTI J.S., 1971 - Five new species of Dendrothrips Uzel, with a key to the Indian species (Thysanoptera: Thripidae). - Orient. Insects 5: 345-359.

FALLAHZADEH M., SAGHAEI N., 2012 - New data on the fauna of Thysanoptera in Fars Province-Iran. - Afr. J. Agric. Res. 7: 5548-5552.

FEKRAT L., MANZARI S., 2014 - First report of Scolothrips dilongicornis (Thysanoptera, Thripidae) from Iran. - J. Entomol. Soc. Iran 34:43-44.

GHOLAMI N., FEKRAT L., MANZARI S., 2014 - First record of Thrips juniperinus (Thys.: Thripidae) from Iran. - J. Entomol. Soc. Iran 34: 65-66.

JAHANGIRI SISAKHT N., HABIBPOUR B., RAMEZANI L., 2014 - The first report of the species Thrips italicus (Thys.: Thripidae) from Iran. J. Entomol. Soc. Iran 34: 21-22 [in Persian].

MARULLO R., 2003 - Host relationships at plant family level Uzel in Dendrothrips (Thysanoptera: Thripidae: Dendrothripinae) with a new Australian species. - Aust. J. Entomol. 42: 46-50.

MINAEI K., 2013 - Thrips (Insecta, Thysanoptera) of Iran: a revised and updated checklist. - Zookeys 330: 53-74.

MINAEI K., 2014a - A new species of Eremiothrips from Iran (Thysanoptera: Thripidae). - Acta Entomol. Mus. Nat. Pragae 54: 29-34.

MINAEI K., 2014b - New record of predatory thrips, Aeolothrips melaleucus (Thysanoptera, Aeolothripidae) from Iran. - Linzer biol. Beitr. 46: 637-642.

MINAEI K., ABDOLLAHI M., 2015 - Predators of leaf-feeding mites, Scolothrips (Thysanoptera: Thripidae), in Iran with first description of the female of Scolothrips tenuipennis. - Zool. Ecol- 25: 36-66.

MINAEI K., ALAVI J., FEKRAT L., ALEOSFOOR M., 2014 - First record of the genus Eryngyothrips from Iran with description of a new species (Thysanoptera: Thripidae). - Acta Entomol. Mus. Nat. Pragae 54: 455-460.

MINAEI K., MOUND LA., 2014a - New synonymy in the wheat thrips, Haplothrips tritici (Thysanoptera: Phlaeothripidae). - Zootaxa 3802: 596-599.

MINAEI K., MOUND LA., 2014b - The genus Sitothrips (Thysanoptera: Thripidae) with a new grass-living species from southern Iran. Zootaxa 3884: 594-596.

MINAEI K., MOUND LA., 2014c - The Liothrips-lineage of thrips (Thysanoptera: Phlaeothripidae) from Iran with the first record of micropterous morph of a Liothrips species. - Zootaxa 3889: 107-117.

MINAEI K., MOUND LA., 2015 - Thysanoptera disjunct distribution between western America and the Mediterranean with a new Psilothrips species (Thripidae) from Iran. - Dtsch. Entomol. Z. 62: 1-7.

MIRAB-BALOU M., 2013 - A newly recorded species of the genus Thrips (Insecta: Thysanoptera) from Iran. - Nat. Monten. 12: 251-254.

MIRAB-BALOU M., 2014a - A newly recorded species of the genus Haplothrips (Insecta: Thysanoptera) from Iran. - J. Crop Prot. 3: 557-561.

MIRAB-BALOU M., 2014b - First report of the genus and species of Nesothrips brevicollis (Bagnall) (Thysanoptera: Phlaeothripidae) from Iran. - J. Crop Prot. 3: 99-103.

MIRAB-BALOU M., JAMALI J., TONG X.L., 2014a - Neohydatothrips ilamensis $\mathrm{n}$. sp. (Insecta: Thysanoptera: a new species from Iran. Arch. Biol. Sci. 66: 969-973.

MIRAB-BALOU M., NOUROLLAHI KH., JAMALI J., 2014b - A new species of the genus Anaphothrips (Thysanoptera: Thripidae) from Ilam province, Iran. - Far East. Entomol. 273: 21-24.

MIRAMIRKHANI N., FEKRAT L. MANZARI, S. SADEGHI NAMGHI H., 2014 - A newyly recorded genus and species of Phlaeothripinae, Karnyothrips flavipes (Jones, 1912) (Thysanoptera: Phlaeothripidae) from Iran. Proceeding of the 21th Iranian Plant Protection Congress. p. 430.

MOUND L.A., 1999 - Saltatorial leaf-feeding Thysanoptera (Thripidae, Dendrothripinae) in Australia and New Caledonia, with newly recorded pests of ferns, figs and mulberries. - Aust. J. Entomol. 38: 257-273.

MOUND L.A., 2011a - Grass-dependent Thysanoptera of the family Thripidae from Australia. - Zootaxa 3064: 1-40.

MOUND L.A., 2011b - Order Thysanoptera Haliday, 1836. pp 201-202 In: ZHANG Z.-Q. (ed.), Animal biodiversity: an outline of higherlevel classification and survey of taxonomic richness. - Zootaxa 3148:1-237. 
MOUND L.A., 2013 - Homologies and host-plant specificity: recurrent problems in the study of thrips. - Fla. Entomol. 96: 318-322.

RAHEMI S., HASHEMI KHABIR Z., SADEGHI SE., MOHARRAMIPOUR S., SHOJAI M., ZEINALI S., 2010 - Report of willow thrips Thrips viminalis Uzel (Thy.: Thripidae) from Iran. - J. Forest Range Protect. Res. 8: 89-91.
THRIPSWIKI, 2015 - ThripsWiki-providing information on the World's thrips. Available from: http://thrips.info/wiki/ Accessed: 10 Jan, 2015.

ZUR STRASSEN R., 2003 - Die terebranten Thysanopteren Europas und des Mittelmeer-Gebietes. - Die Tierwelt Deutschlands und der angrenzenden Meeresteile 74: 1-277 [in German]. 